\title{
Optimized Assay for Hydrogen Peroxide Determination in Plant Tissue Using Potassium Iodide
}

\author{
Sanders Junglee, Laurent Urban, Huguette Sallanon, Félicie Lopez-Lauri \\ Laboratoire de Physiologie des Fruits et Légumes, Université d’Avignon et des Pays du Vaucluse, Avignon, \\ France \\ Email: felicie.lauri@univ-avignon.fr
}

Received 7 June 2014; revised 23 July 2014; accepted 6 August 2014

Copyright (C) 2014 by authors and Scientific Research Publishing Inc.

This work is licensed under the Creative Commons Attribution International License (CC BY). http://creativecommons.org/licenses/by/4.0/

c) (i) Open Access

\begin{abstract}
Here, we present an optimization of colorimetric determination of hydrogen peroxide content in plants using potassium iodide. Our method is based on a one step buffer (extraction and reaction) for the determination of $\mathrm{H}_{2} \mathrm{O}_{2}$ in different plant tissues and overcomes interference of soluble antioxidant and color background. A particular attention is paid to buffer pH shown to be tissue dependent. With this inexpensive microplate method, it is possible to analyze 12 experimental samples in about $45 \mathrm{~min}$ all in triplicates, with blanks, controls and standard curve.
\end{abstract}

\section{Keywords}

Hydrogen Peroxide, Potassium Iodide, One Step, Microplate, Inexpensive

\section{Introduction}

Hydrogen peroxide $\left(\mathrm{H}_{2} \mathrm{O}_{2}\right)$ is commonly produced in plants during normal physiological processes and in response to stress situations [1]. The quantitative determination of hydrogen peroxide is important in numerous studies since $\mathrm{H}_{2} \mathrm{O}_{2}$ is involved in oxidative cellular damages as well as in signalling processes [2] [3]. Owing to its importance, numerous methods and kits have been developed based on spectrophotometry, chemiluminescence [4], enzymatic method [5] and electrochemistry [6]. However, some of these methods are very expensive. Several years ago, an economic colorimetric method has been described for the determination of $\mathrm{H}_{2} \mathrm{O}_{2}$ [7] and it is widely used in the field of plant biology [8]-[10]. This method is based on potassium iodide (KI) oxidation by $\mathrm{H}_{2} \mathrm{O}_{2}$ in acidic medium according to the following equations:

$$
2 \mathrm{I}^{-}+2 \mathrm{H}^{+}+\mathrm{H}_{2} \mathrm{O}_{2} \rightarrow \mathrm{I}_{2}+2 \mathrm{H}_{2} \mathrm{O}
$$




$$
\mathrm{I}_{2}+\mathrm{I}^{-} \rightarrow \mathrm{I}_{3}^{-}
$$

When hydrogen peroxide is added to colorless solution of potassium iodide $(\mathrm{KI})$, the iodide ions $\left(\mathrm{I}^{-}\right)$are slowly oxidized in iodine $\left(\mathrm{I}_{2}\right)$. In presence of iodide, iodine reacts to form triiodide $\left(\mathrm{I}_{3}^{-}\right)$resulting in a yellowish solution. Therefore hydrogen peroxide could be quantified by spectrophotometric method by following $\mathrm{I}_{3}^{-}$absorption. In the method described by Velikova et al. (2000), $\mathrm{H}_{2} \mathrm{O}_{2}$ determination relies on absorbance at $390 \mathrm{~nm}$. However, the triiodide absorbs at 285 and $350 \mathrm{~nm}$ as presented in Figure 1(a). Although the peak observed at $285 \mathrm{~nm}$ presents greater sensitivity, the peak at $350 \mathrm{~nm}$ has been used in this study. Indeed plant tissues show important absorption at $285 \mathrm{~nm}$, which can interfere with the assay (Figure 1(b), Figure 1(c)). Plant extracts have a colour background to take into account and contain molecules that interfere with $\mathrm{H}_{2} \mathrm{O}_{2}$ determination. Figure 1(b) and Figure 1(c) show no difference between the reaction spectra from tomato fruit and leaf extracts with KI or not. The purpose of this work was to optimize the iodometric assay for plant tissues.

Commonly, metabolite determination is made through two major steps: extraction of molecules from tissue and quantification of molecule of interest from this extract. However using the two-step protocol, $\mathrm{H}_{2} \mathrm{O}_{2}$ might be destroyed by ascorbic acid, which is an efficient $\mathrm{H}_{2} \mathrm{O}_{2}$ scavenger [11], during extraction step and may be underestimated or cannot be quantified at all (Table 1(a)). So, we proposed an alternative one-step method.

Table 1. (a) $\mathrm{H}_{2} \mathrm{O}_{2}$ concentration measured in absence and presence of 1 nmole ascorbic acid added before KI or together with KI; (b) Influence of the ratio of tomato tissue to buffer on hydrogen peroxide concentration. Statistical significance was determined with student t-test ( $p<0.05$ ) with "R" 2.12.2 statistical software (www.cran.rproject.org); (c) Hydrogen peroxide content in fruits and leaves of tomato plants treated or not with $\mathrm{HgCl}_{2}$ using the optimized protocol. Statistical significance was determined by student t-test $(p<0.05)$ with "R" 2.12 .2 statistical software (www.cran.rproject.org).

(a)

\begin{tabular}{ccc}
\hline \multirow{2}{*}{ Expected $\mathbf{H}_{2} \mathbf{O}_{2}$ concentration (nmole) } & \multicolumn{2}{c}{ Measured $\mathbf{H}_{2} \mathbf{O}_{2}$ concentration (nmole) } \\
\cline { 2 - 3 } $\mathbf{0}$ & 1 nmol ASA added before KI & 1 nmol ASA added together with KI \\
$\mathbf{1}$ & $0.00 \pm 0.00$ & $0.00 \pm 0.01$ \\
$\mathbf{2}$ & $0.00 \pm 0.00$ & $0.82 \pm 0.04$ \\
$\mathbf{3}$ & $0.00 \pm 0.00$ & $1.78 \pm 0.13$ \\
$\mathbf{4}$ & $0.32 \pm 0.00$ & $2.68 \pm 0.13$ \\
$\mathbf{5}$ & $1.46 \pm 0.09$ & $3.65 \pm 0.03$ \\
$\mathbf{6}$ & $2.43 \pm 0.03$ & $4.44 \pm 0.06$ \\
\hline
\end{tabular}

(b)

\begin{tabular}{ccc}
\hline $\mathbf{m g ~ F W / m l ~}$ & $\mathbf{H}_{2} \mathbf{O}_{2}(\mathbf{n m o l} / \mathbf{g})$ \\
\hline $\mathbf{5 0}$ & $491.20 \pm 18.74^{\mathrm{a}}$ \\
$\mathbf{1 0 0}$ & $528.86 \pm 0.61^{\mathrm{a}}$ \\
$\mathbf{1 5 0}$ & $612.10 \pm 17.53^{\mathrm{b}}$ \\
$\mathbf{2 0 0}$ & $584.33 \pm 12.45^{\mathrm{a}}$ \\
$\mathbf{2 5 0}$ & $377.96 \pm 15.78^{\mathrm{c}}$ \\
\hline
\end{tabular}

(c)

\begin{tabular}{ccc}
\hline Organ & Treatment & $\mathbf{H}_{2} \mathbf{O}_{2}(\mathbf{n m o l} / \mathbf{g F W})$ \\
\hline \multirow{2}{*}{ Fruits } & Control & $77.16 \pm 9.07^{\mathrm{a}}$ \\
& $5 \mathrm{ppm} \mathrm{HgCl}$ & $175.73 \pm 5.79^{\mathrm{b}}$ \\
Leaves & Control & $472.57 \pm 8.73^{\mathrm{a}}$ \\
& $5 \mathrm{ppm} \mathrm{HgCl}_{2}$ & $836.97 \pm 9.85^{\mathrm{b}}$ \\
\hline
\end{tabular}




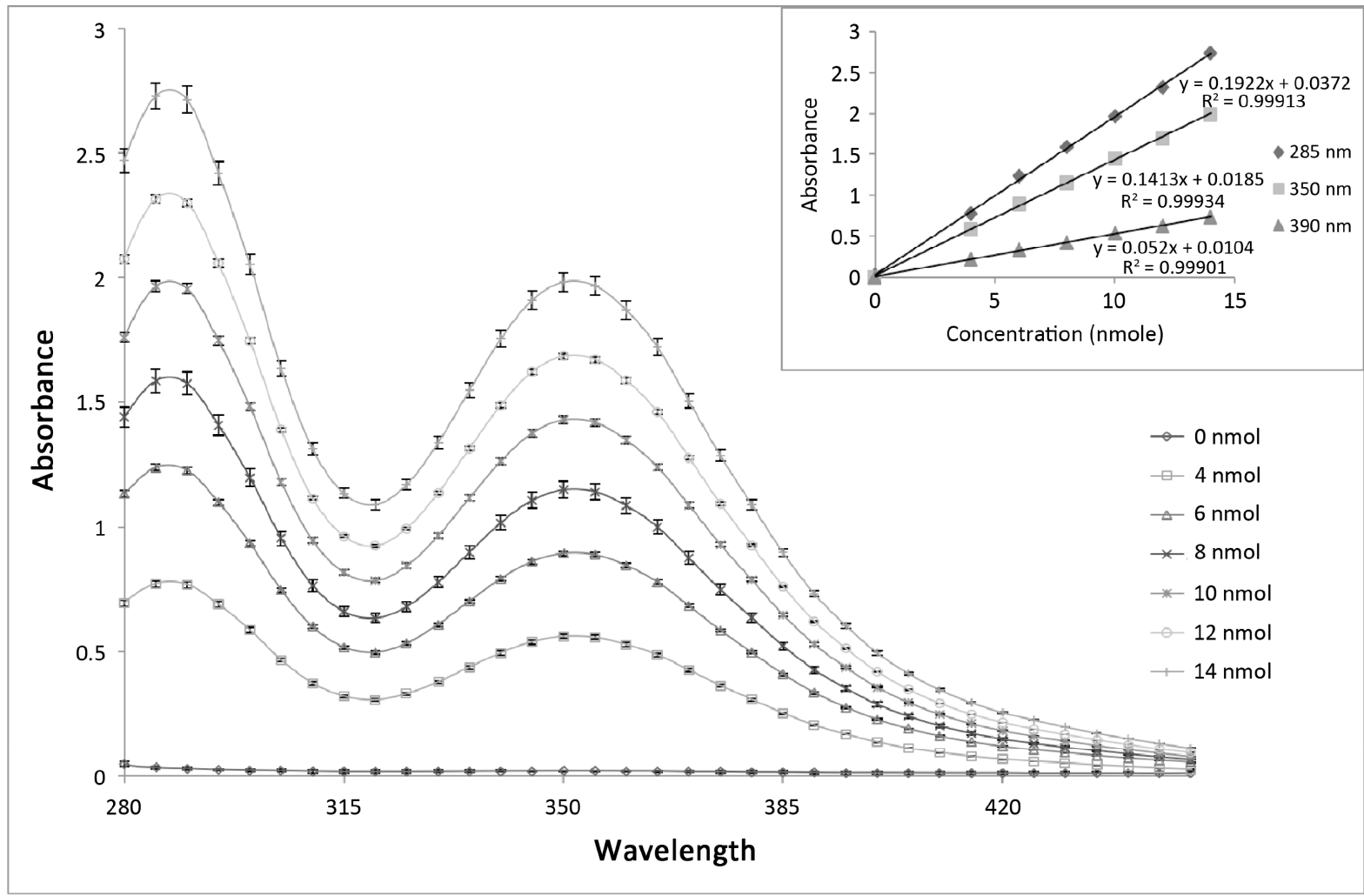

(a)

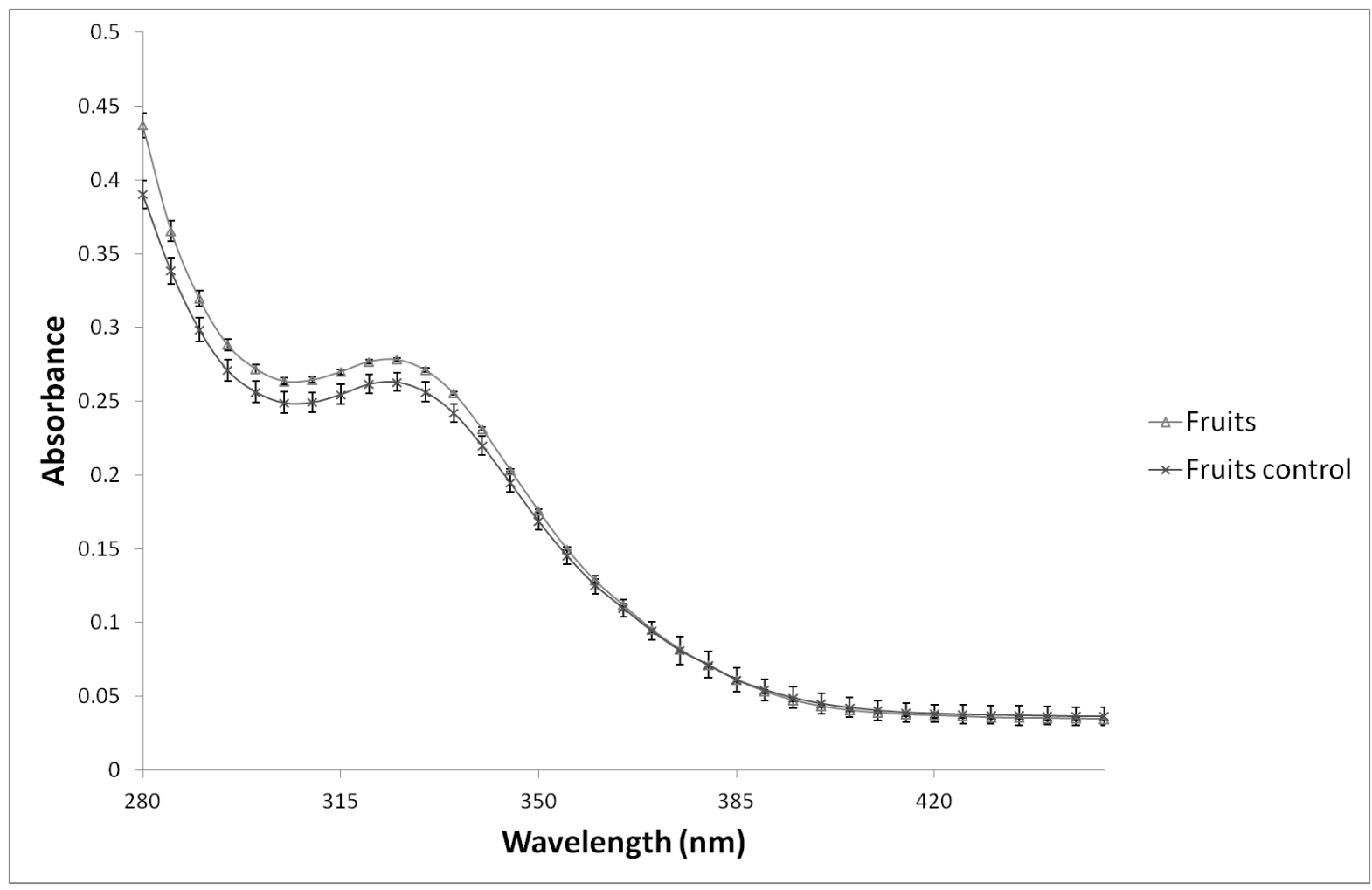

(b) 


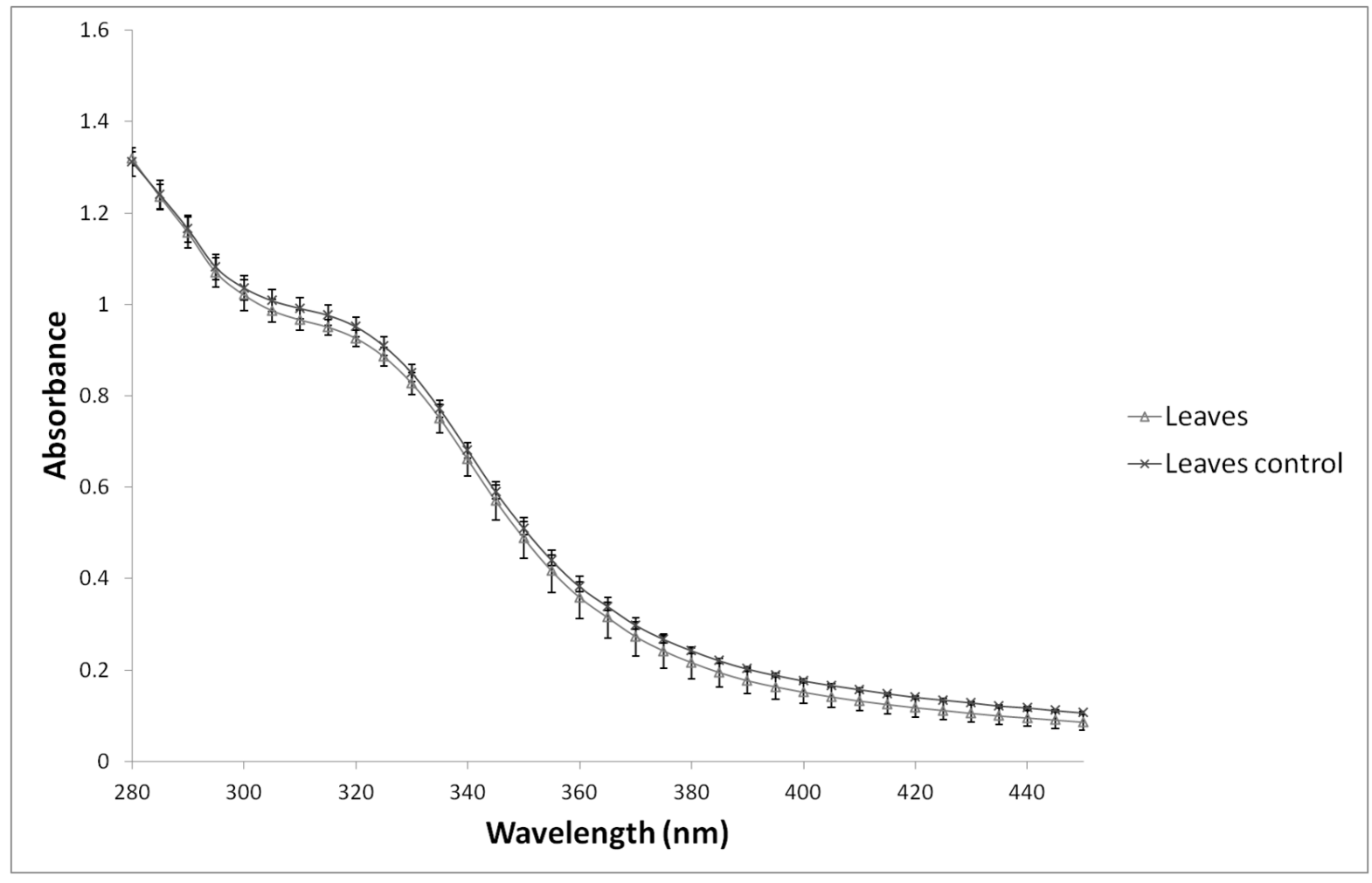

(c)

Figure 1. (a) Absorption spectra of $\mathrm{I}_{3}^{-}$ions resulting from hydrogen peroxide $\left(\mathrm{H}_{2} \mathrm{O}_{2}\right)$ reaction with potassium iodide (KI 1 M) using different $\mathrm{H}_{2} \mathrm{O}_{2}$ concentrations in $0.1 \%$ TCA. Inset shows calibration curve with slopes for hydrogen peroxide quantification measured at 350 and $390 \mathrm{~nm}$ at $\mathrm{pH} 7$; (b) Absorption spectra of hydrogen peroxide $\left(\mathrm{H}_{2} \mathrm{O}_{2}\right)$ reaction with potassium iodide (KI $1 \mathrm{M}$ ) in $0.1 \%$ TCA at pH 7 with Velikova et al. (2000) method. Fruit: Fruit homogenate in presence of KI. Fruit control: Fruit homogenate in absence of KI. Each value represents mean \pm standard deviation; (c) Absorption spectra of hydrogen peroxide $\left(\mathrm{H}_{2} \mathrm{O}_{2}\right)$ reaction with potassium iodide $(\mathrm{KI} 1 \mathrm{M})$ in $0.1 \%$ TCA at pH 7 with Velikova et al. (2000) method. Leaves: Leaf homogenate in presence of KI. Leaves control: Leaf homogenate in absence of KI. Each value represents mean \pm standard deviation.

\section{Materials and Methods}

The protocol is as follows: tomato fruits were harvested, immediately frozen in liquid nitrogen, ground and the powder stored at $-80^{\circ} \mathrm{C}$ until $\mathrm{H}_{2} \mathrm{O}_{2}$ determination assay. Frozen powder (150 mg) was directly homogenized with $1 \mathrm{ml}$ of solution containing $0.25 \mathrm{ml}$ Trichloroacetic acid (TCA) (0.1\% (w:v)), $0.5 \mathrm{ml} \mathrm{KI} \mathrm{(1} \mathrm{M)} \mathrm{and} 0.25 \mathrm{ml}$ potassium phosphate buffer $\left(10 \mathrm{mM}\right.$, pH adapted to studied tissue) at $4^{\circ} \mathrm{C}$ for $10 \mathrm{~min}$ (one-step buffer: extraction and colorimetric reaction combined). At the same time, for every sample, a control was prepared with $\mathrm{H}_{2} \mathrm{O}$ instead of KI for tissue coloration background. Good care was taken to protect samples and solutions from light. The homogenate was centrifuged at $12,000 \times g$ for $15 \mathrm{~min}$ at $4^{\circ} \mathrm{C} .200 \mu \mathrm{L}$ of supernatant from each tube were placed in UV-microplate wells and left to incubate at room temperature $\left(20^{\circ} \mathrm{C}-22^{\circ} \mathrm{C}\right)$ for 20 min. Samples and blanks were analyzed in triplicate. A calibration curve obtained with $\mathrm{H}_{2} \mathrm{O}_{2}$ standard solutions prepared in $0.1 \%$ TCA was used for quantification (Figure 1(a)). The microplate reader used is a Power Wave HT microplate spectrophotometer from BioTek (France) equipped with an internal temperature incubator and shaker for kinetic and spectrum analysis. We used the KC4 data software to check the reader and to analyze reactions. To optimize the protocol, assays have been done by modifying $\mathrm{pH}$ of phosphate buffer. As shown in Figure 2(a), tomato fruit extracts exhibited maximum absorbance at $350 \mathrm{~nm}$ in $10 \mathrm{mM}$ potassium phosphate buffer solution at $\mathrm{pH}$. For tomato leaves the most efficient buffer for the reaction was at $\mathrm{pH} 5.8$ (Figure 2(c)). The kinetic of the reaction was not modified by the modification of the buffer $\mathrm{pH}$ as shown in Figure 2(b) and Figure 2(d).

In addition, the influence of the ratio of tomato exocarp to “one-step buffer" was made in order to select the 
ratio that resulted in maximal $\mathrm{H}_{2} \mathrm{O}_{2}$ determination (Table $1(b)$ ). The best ratio adapted to our sample was found to be between 150 and $200 \mathrm{mg}$ for $1 \mathrm{ml}$ of buffer. Recovery assays with $20 \mathrm{nmol} / \mathrm{ml} \mathrm{H}_{2} \mathrm{O}_{2}$ made to complete the method revealed $100 \%$ recovery in 100,150 and $200 \mathrm{mg}$. In order to confirm the efficiency of our assay, we compared the $\mathrm{H}_{2} \mathrm{O}_{2}$ contents in fruits (30 days after anthesis) and mature leaves from control plants and plants exposed to $\mathrm{HgCl}_{2}$ (5 ppm) for $24 \mathrm{~h}$, using the new protocol. The results are presented in Table 1 (c).

\section{Conclusion}

This optimized spectrophotometric method based on a one-step buffer (extraction and reaction) is suitable and

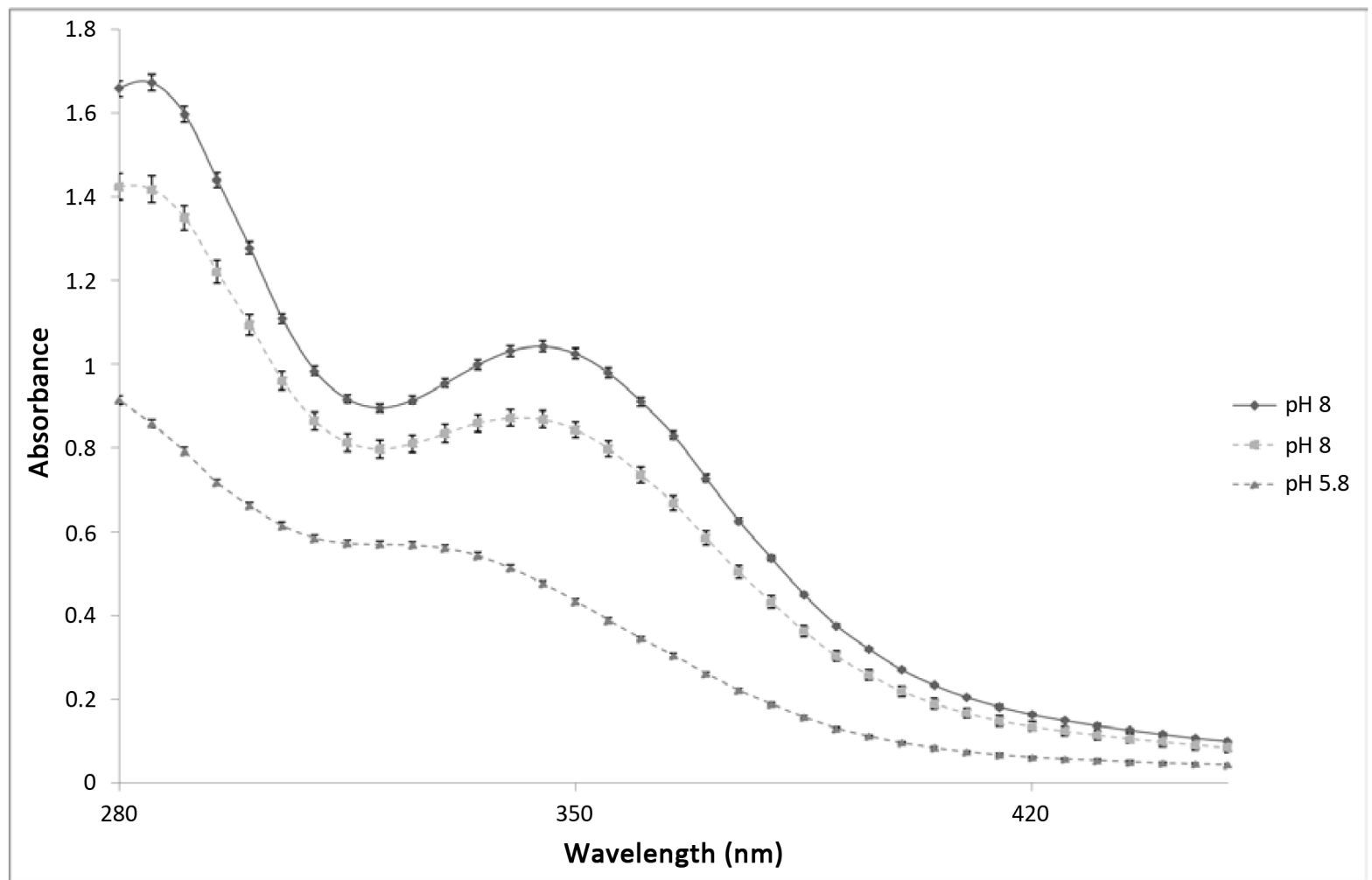

(a)

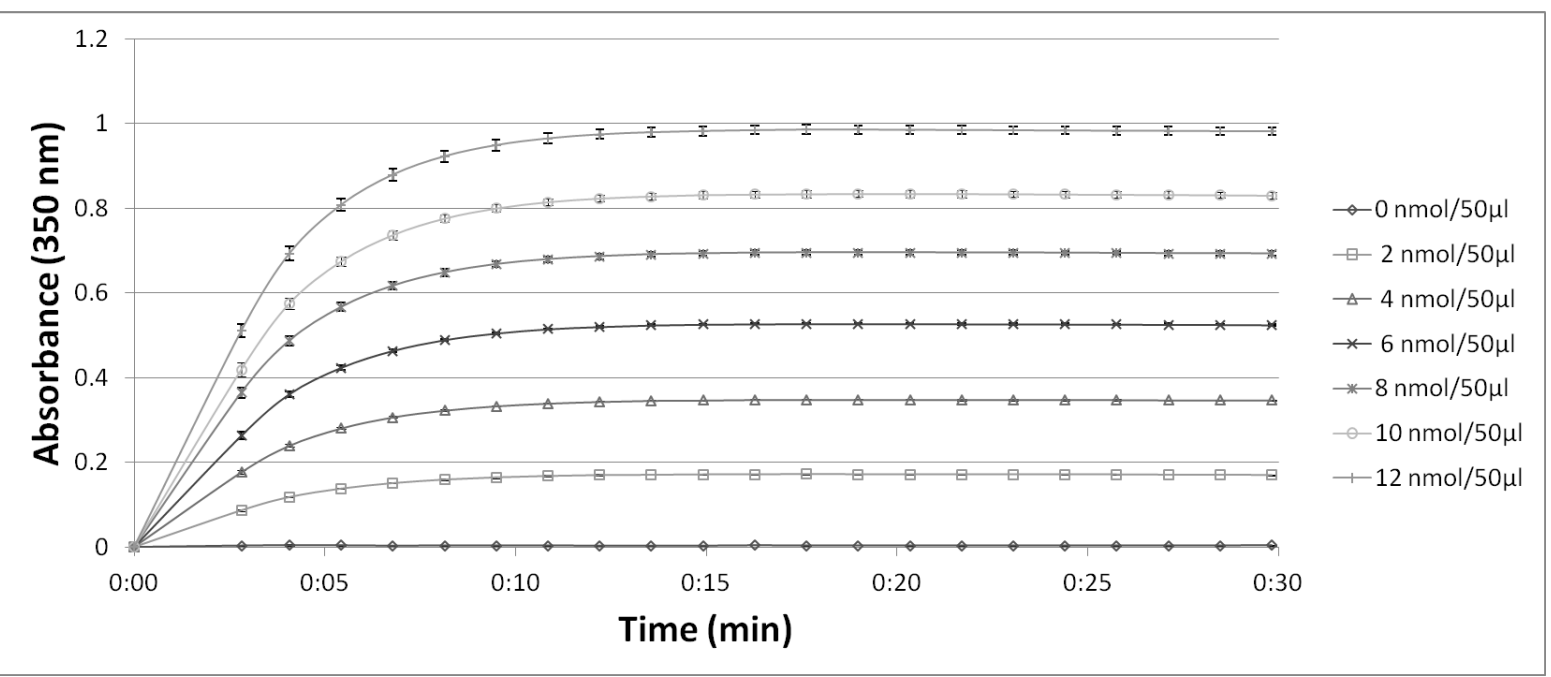

(b) 


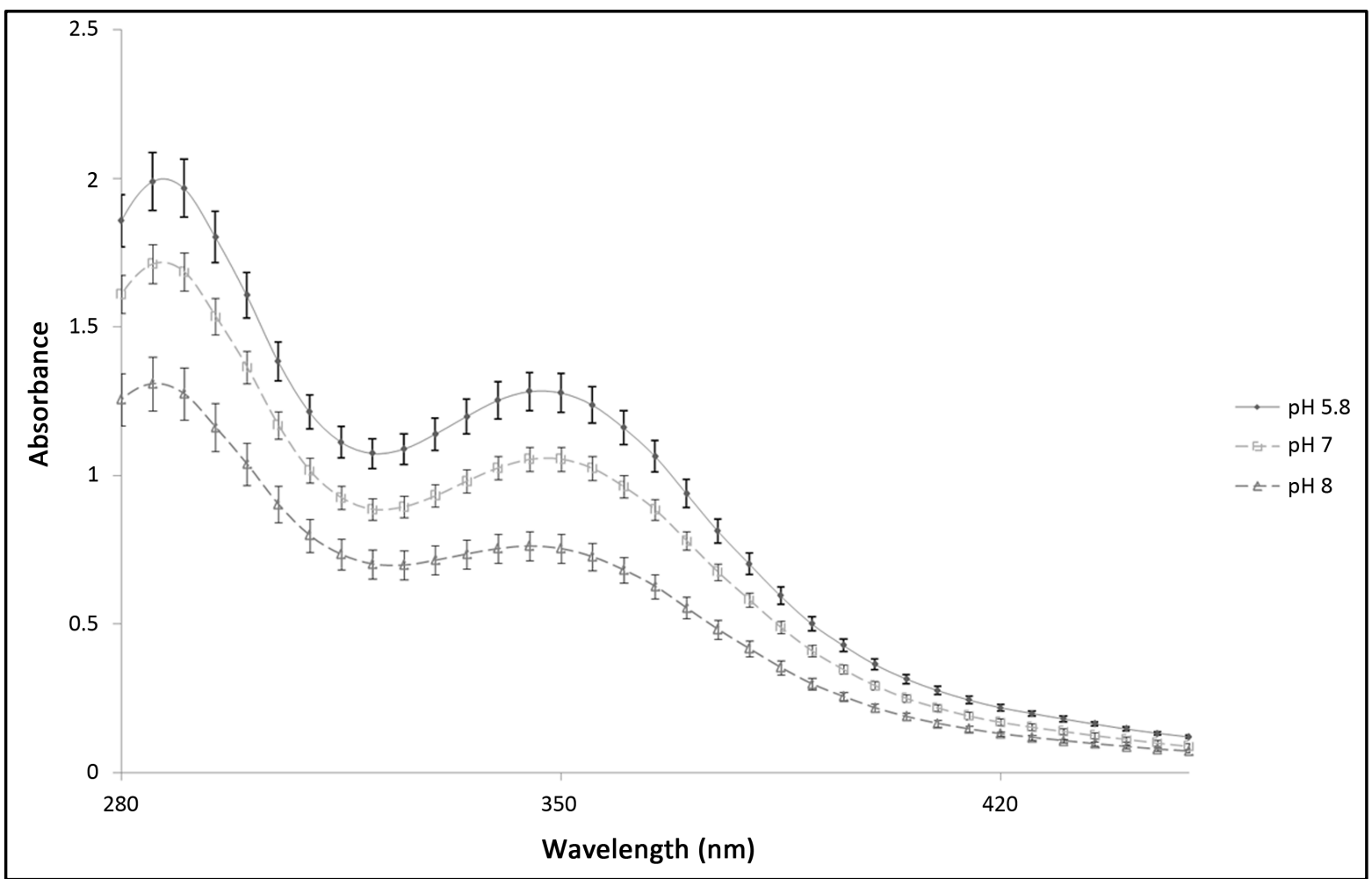

(c)

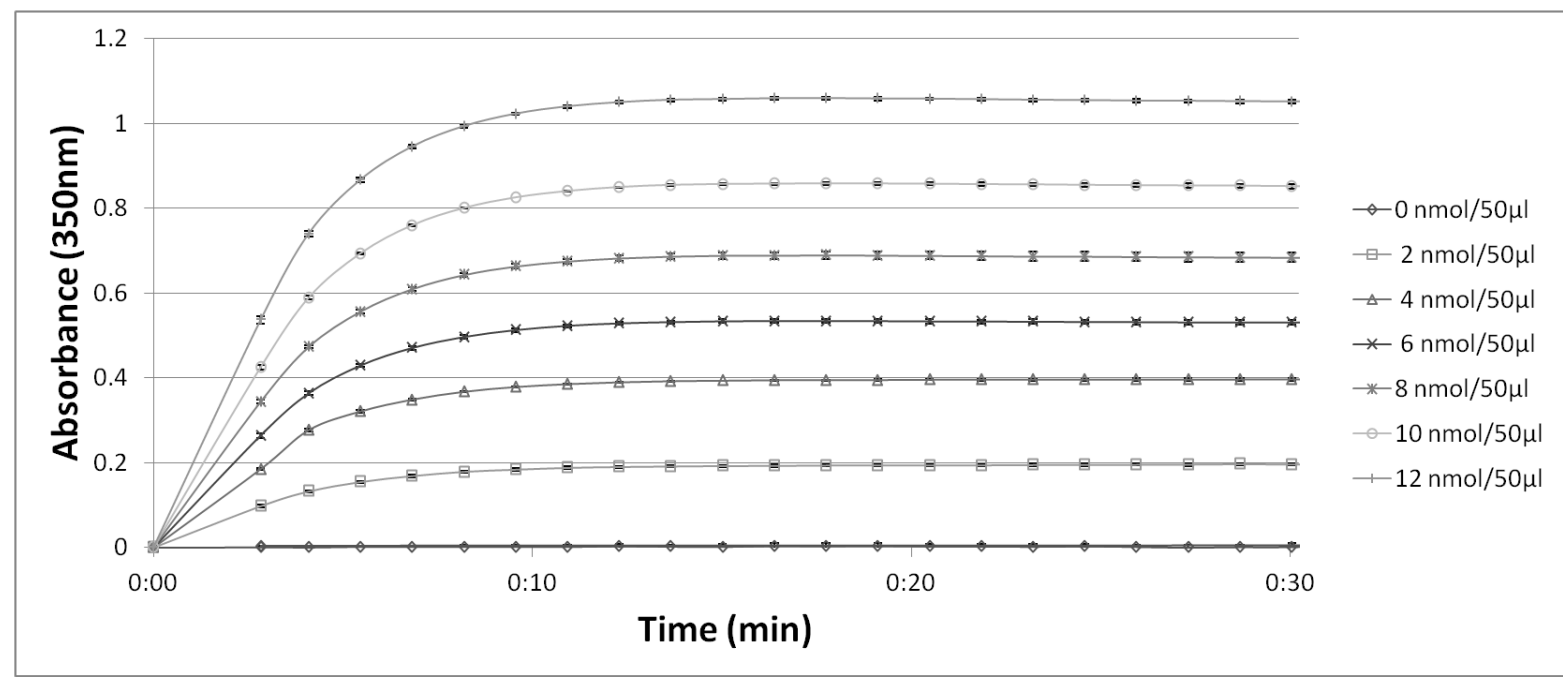

(d)

Figure 2. (a) Absorption spectra of hydrogen peroxide $\left(\mathrm{H}_{2} \mathrm{O}_{2}\right)$ reaction with potassium iodide (KI $\left.1 \mathrm{M}\right)$ in fruits in $0.1 \%$ TCA at pH 5.8, pH 7 and pH 8. Highlighting better absorbance of fruit samples at pH 8 together with an absence of pH interference in background tissue coloration. Each value represents mean \pm standard deviation; (b) Reaction kinetic of reaction between hydrogen peroxide $\left(\mathrm{H}_{2} \mathrm{O}_{2}\right)$ and potassium iodide $(\mathrm{KI} 1 \mathrm{M})$ at $\mathrm{pH} 8$ showing end of reaction after 20 min; (c) Absorption spectra of hydrogen peroxide $\left(\mathrm{H}_{2} \mathrm{O}_{2}\right)$ reaction with potassium iodide $(\mathrm{KI} 1 \mathrm{M})$ in leaves in $0.1 \%$ TCA at $\mathrm{pH} 5.8$, $\mathrm{pH} 7$ and $\mathrm{pH}$ 8. Highlighting better absorbance of leaf samples at $\mathrm{pH} 5.8$ together with an absence of $\mathrm{pH}$ interference in background tissue coloration. Each value represents mean \pm standard deviation; (d) Reaction kinetic of reaction between hydrogen peroxide $\left(\mathrm{H}_{2} \mathrm{O}_{2}\right)$ and potassium iodide $(\mathrm{KI} 1 \mathrm{M})$ at $\mathrm{pH} 5.8$ showing end of reaction after $20 \mathrm{~min}$.

reliable for the determination of $\mathrm{H}_{2} \mathrm{O}_{2}$ in different plant tissues. Indeed, this method allows overcoming interference of soluble antioxidant and color background. With this inexpensive microplate method, it is possible to 
analyze 12 experimental samples in about $45 \mathrm{~min}$ all in triplicates, with blanks, controls and standard curve.

\section{References}

[1] Foyer, C.H. and Shigeoka, S. (2011) Understanding Oxidative Stress and Antioxidant Functions to Enhance Photosynthesis. Plant Physiology, 155, 93-100. http://dx.doi.org/10.1104/pp.110.166181

[2] Neill, S., Desikan, R. and Hancock, J. (2002) Hydrogen Peroxide Signalling. Current Opinion in Plant Biology, 5, 388395. http://dx.doi.org/10.1016/S1369-5266(02)00282-0

[3] Apel, K. and Hirt, H. (2004) Reactive Oxygen Species: Metabolism, Oxidative Stress, and Signal Transduction. Annual Review of Plant Biology, 55, 373-399. http://dx.doi.org/10.1146/annurev.arplant.55.031903.141701

[4] Lu, S., Song, J. and Campbell-Palmer, L. (2009) A Modified Chemiluminescence Method for Hydrogen Peroxide Determination in Apple Fruit Tissues. Scientia Horticulturae, 120, 336-341. http://dx.doi.org/10.1016/j.scienta.2008.11.003

[5] Nagaraja, P., Shivakumar, A. and Shrestha, A.K. (2009) Quantification of Hydrogen Peroxide and Glucose Using 3Methyl-2-benzothiazolinonehydrazone Hydrochloride with 10,11-Dihydro-5H-benz(b,f)azepine as Chromogenic Probe. Analytical Biochemistry, 395, 231-236. http://dx.doi.org/10.1016/j.ab.2009.07.053

[6] Liu, X. and Zweier, J.L. (2001) A Real-Time Electrochemical Technique for Measurement of Cellular Hydrogen Peroxide Generation and Consumption: Evaluation in Human Polymorphonuclear Leukocytes. Free Radical Biology and Medicine, 31, 894-901. http://dx.doi.org/10.1016/S0891-5849(01)00665-7

[7] Velikova, V., Yordanov, I. and Edreva, A. (2000) Oxidative Stress and Some Antioxidant Systems in Acid RainTreated Bean Plants: Protective Role of Exogenous Polyamines. Plant Science, 151, 59-66. http://dx.doi.org/10.1016/S0168-9452(99)00197-1

[8] Sengupta, D., Guha, A. and Reddy, A.R. (2013) Interdependence of Plant Water Status with Photosynthetic Performance and Root Defense Responses in Vigna radiata (L.) Wilczek under Progressive Drought Stress and Recovery. Journal of Photochemistry and Photobiology B: Biology, 127, 170-181. http://dx.doi.org/10.1016/j.jphotobiol.2013.08.004

[9] Girotto, E., Ceretta, C.A., Rossato, L.V., Farias, J.G., Tiecher, T.L., De Conti, L., Schmatz, R., Brunetto, G., Schetinger, M.R.C. and Nicoloso, F.T. (2013) Triggered Antioxidant Defense Mechanism in Maize Grown in Soil with Accumulation of $\mathrm{Cu}$ and $\mathrm{Zn}$ Due to Intensive Application of Pig Slurry. Ecotoxicology and Environmental Safety, 93, 145-155. http://dx.doi.org/10.1016/j.ecoenv.2013.03.021

[10] Nounjan, N., Nghia, P.T. and Theerakulpisut, P. (2012) Exogenous Proline and Trehalose Promote Recovery of Rice Seedlings from Salt-Stress and Differentially Modulate Antioxidant Enzymes and Expression of Related Genes. Journal of Plant Physiology, 169, 596-604. http://dx.doi.org/10.1016/j.jplph.2012.01.004

[11] Noctor, G. and Foyer, C. (1998) Ascorbate and Glutathione: Keeping Active Oxygen under Control. Annual Review of Plant Physiology and Plant Molecular Biology, 49, 249-279. http://dx.doi.org/10.1146/annurev.arplant.49.1.249 